\title{
EHMTI-0396. Reappearance of high fever on migraine patients, after individualized homeopathic treatment, is a valuable prognostic factor
}

\author{
S Kivellos ${ }^{1 *}$, S Skifti', G Vithoulkas ${ }^{2}$ \\ From 4th European Headache and Migraine Trust International Congress: EHMTIC 2014 \\ Copenhagen, Denmark. 18-21 September 2014
}

\section{Background}

Nine years experience of introduction of Homeopathy at Headache Clinic of a major Public Hospital.

\section{Aim}

To reproduce the positive results of a previous study presented in EHTIC 2008.

\section{Methods}

One hundred and twenty migraine patients assigned to receive individualized homeopathic treatment. Additional evaluation by a neurologist was performed at baseline, 6 and 12 months. Primary and secondary measures of migraine severity and impact on quality of life were recorded and analyzed.

\section{Results}

Eighty two patients opted only for homeopathic treatment until the completion of the study, with a baseline HIT-6 score of $67 \pm 4$. Significant improvement was recorded at 6 months (HIT-6 $45 \pm 8, \mathrm{P}<0.0009$ vs baseline, Wilcoxon signed ranks test), further established at 12 months (HIT$640.2 \pm 7, \mathrm{P}<0.0009$ vs 6 months). Migraine severity (VAS) decreased by $72 \%$ and frequency by $81 \%$ at 12 months $(\mathrm{P}<0.0001$ vs baseline). Observed potential adverse effects were an initial 'aggravation' of migraine symptoms in $69 \%$, recurrence of past medical diseases , especially infections or upper respiratory with high fever in $62 \%$.

"Headache Clinic, "G.Gennimatas" Athens General Hospital, Athens, Greece Full list of author information is available at the end of the article

\section{Conclusion}

More positive results and more reappearance of high fever infections appeared in this study after following G. Vithoulkas' instructions.

Original videos of many patients describing the unexpected reappearance of very high fever, after a long time, will be presented.

No conflict of interest.

\section{Authors' details}

"Headache Clinic, "G.Gennimatas" Athens General Hospital, Athens, Greece. ${ }^{2}$ Academic Dept, International Academy of Classical Homeopathy, Alonnisos, Greece.

Published: 18 September 2014

\section{doi:10.1186/1129-2377-15-S1-M7}

Cite this article as: Kivellos et al:: EHMTI-0396. Reappearance of high fever on migraine patients, after individualized homeopathic treatment, is a valuable prognostic factor. The Journal of Headache and Pain 2014 15(Suppl 1):M7.

Submit your manuscript to a SpringerOpen ${ }^{\bullet}$ journal and benefit from:

- Convenient online submission

- Rigorous peer review

- Immediate publication on acceptance

- Open access: articles freely available online

- High visibility within the field

Retaining the copyright to your article

Submit your next manuscript at $>$ springeropen.com

\section{SpringerOpen $^{\circ}$}

(C) 2014 Kivellos et al; licensee Springer. This is an Open Access article distributed under the terms of the Creative Commons Attribution License (http://creativecommons.org/licenses/by/2.0), which permits unrestricted use, distribution, and reproduction in any medium, provided the original work is properly cited. 